\title{
AN INTEGRATED EXPLORATION APPROACH TO MAP BIF-HOSTED GOLD DEPOSITS IN THE RIO DAS VELHAS GREENSTONE BELT, QUADRILÁTERO FERRÍFERO, BRAZIL
}

\author{
ADALENE MOREIRA SILVA ${ }^{1,3}$, ANNE E. MCCAFFERTY ${ }^{2} \&$ AUGUSTO CÉSAR B. PIRES $^{3}$
}

\begin{abstract}
Resumo ABORDAGEM EXPLORATÓRIA INTEGRADA VISANDO O MAPEAMENTO DE DEPÓSITOS AURÍFEROS HOSPEDADOS NO GREENSTONE BELT RIO DAS VELHAS, QUADRILÁTERO FERRIFERO O principal enfoque deste artigo é o desenvolvimento de uma técnica de mapeamento por meio de razões de probabilidade e sua aplicação na estimativa da distribuição de depósitos auríferos hospedados em formações ferríferas bandadas (BIF), fácies óxido, no Greenstone Belt Rio das Velhas, Quadrilátero Ferrífero. Os modelos de razão de probabilidade usam a distribuição espacial dos BIFs para calcular diferentes assinaturas de mineralizações auríferas. A habilidade dos modelos em prever regiões favoráveis a mineralizações auríferas econômicas foi verificada por meio da comparação destas regiões com as rochas hospedeiras e com as ocorrências de depósitos hospedados no greenstone belt Rio das Velhas. Do ponto de vista regional, os modelos de previsão geofísica são convincentes na definição da maioria das rochas hospedeiras. Os modelos de previsão gerados para as formações ferríferas bandadas mostram novas áreas prospectivas com o potencial de conter mineralizações auríferas. Um novo alvo foi mapeado utilizando a técnica em questão e foi checado em trabalho de campo. Este alvo representa uma validação que encoraja estudos de follow-up no Greenstone Belt Rio das Velhas e pode significar um forte incremento nas chances de sucesso de exploração mineral na área.
\end{abstract}

Palavras-chaves: razões de probabilidade, formações ferríferas bandadas, Greenstone Belt Rio das Velhas, seleção de alvos para ouro, novo alvo.

\begin{abstract}
A statistical modeling approach was applied to airborne geophysical data to locate areas favorable for gold mineralization in Rio das Velhas Greenstone Belt, Quadrilátero Ferrífero (QF). A positive spatial coincidence exists between banded iron formation (BIF) host-rocks, structures, and mineralogy that are indicative of gold mineralization. Quantitative relationships between airborne geophysical and geological data with known gold occurrences were determined and combined to produce predictive models to explore for Archean oxide-BIF-hosted deposits. Results map areas within exposed and subsurface rocks favorable for gold mineralization. Selected target areas for gold mineralization were checked in the field and provide validation that encourages future ground follow-up in the Rio das Velhas Greenstone Belt. The approach used in this study has shown great capability for linking geological and geophysical data and illustrates an approach that may significantly increase the odds of exploration success in the area.
\end{abstract}

Keywords: Probability Ratio Mapping Technique, Quadrilátero Ferrífero, Rio das Velhas Greenstone Belt, Oxide-type BIF, new target.

INTRODUCTION In the Quadrilátero Ferrífero $(\mathrm{QF})$ region, many exploration surveys have been conducted based on old prospects, geological and geochemical mapping. These efforts were the primary tools responsible for many gold discoveries. Limited outcrops and a thick soils pose serious logistical constraints to finding new deposits in this region (Ladeira 1980, Pinto 1996, Silva 1999). Because of the extensive cover, there is a higher than usual likelihood that undiscovered deposits exists. Hidden mineral deposits are prime targets for geophysical methods, which image the third dimension that mapping geologists can only infer. The availability of airborne geophysical survey data combined with GIS (geographic information system) now allow emphasis to be placed on mapping as well as subsurface features related to mineralization in the Quadrilátero Ferrífero region (Silva 1999).

Most mineral deposits are a spatially small part (less than $3 \mathrm{~km}^{2}$ ) of a mineralized system (Jaques et al. 1997), which can occur over a scale of tens of kilometers (district scale) or hundreds of kilometers (regional scale). The Rio das Velhas Greenstone Belt is located within the QF and is characterized by world-class gold production in regard to deposits hosted in banded iron formation of the Algoma type. In the Rio das Velhas Greenstone Belt case, much of the exploration effort has focused on deposits with obvious surface expression. Such deposits commonly have a regional and/or local magnetic and/or radiometric and/or electromagnetic signature, many of which were mapped by Rio das Velhas airborne survey.

Although spatial data integration methods are being used increasingly for mineral resource assessments, a preferred methodology is by no means established. The purpose of combining various geologic, geophysical, and geochemical information is to identify and describe spatial associations present in the data, and to develop models for analysis and prediction of spatial phenom-

1 - Departamento de Geologia e Recursos Naturais, Instituto de Geociências, Unicamp, Campinas, SP, Brazil, 13083-970 (adalene@ige.unicamp.br)

2 - United States Geological Survey, Box 25046, Mail Stop 964, Denver Federal Center, Denver, CO, USA, 80225 (anne@usgs.gov)

3 - Laboratório de Geofísica Aplicada, Instituto de Geociências, Universidade de Brasília, Brasília, DF, Brazil, 70910-900 (acbpires@unb.br) 
ena (Bonham-Carter 1994).

This paper discusses a quantitative data integration approach for establishing areas of mineral potential for oxide-type BIF of Rio das Velhas Greenstone Belt, Quadrilátero Ferrífero, currently an important area for gold exploration. The general goal of this study is to combine information from the known geology, airborne geophysics, and mineral occurrences to map areas favorable for gold mineralization on an intermediate regional scale (1:100 000). Emphasis is placed on predicting the distribution of BIF-Archeanhosted-gold mineralization using the probability ratio method (Silva 1999, Lee et al. 2001). Results of the predictive models are evaluated with ground geologic field investigations to establish their validity.

GEOLOGIC OVERVIEW The QF is located in the southern portion of the São Francisco Craton and is composed of Archean granite-gneissic terrains (GGTs), Archean Greenstone Belt (Rio das Velhas Supergroup), Paleoproterozoic (Minas Supergroup and Itacolomi Group) and Paleoproterozoic-Mesoproterozoic (Espinhaço Supergroup) supracrustal units (Fig. 1).

The supracrustal units of the Minas and Rio das Velhas Supergroups, surround and are surrounded by granite-gneiss domes and each has been named: Bação, Caeté, Bonfim, Belo Horizonte and Santa Rita. These domes consist of poly-deformed gneiss, metatonalites to metagranites, amphibolites, meta-ultramafic rocks, as well as pegmatites formed under amphibolite facies conditions during the Archean and the Tranzamazonic Eras (Cordani et al. 1980). The contact with adjacent supracrustal units is tectonic.

The Rio das Velhas Supergroup (RVSG - 3.0-2.7 Ga) is divided in two groups. The first, Nova Lima Group (NLG) comprises a lower ultramafic unit, an intermediate felsic-mafic unit and a clastic-mafic-felsic unit (Ladeira 1980). These rocks are overlain by quartzites of Maquiné Group.

Zuchetti et al. (1996) divided the Rio das Velhas Supergroup into informal lithostratigraphic units based on field observations, petrologic and geochemical studies. Pinto \& Silva (1996) proposed the upgrading of these units to formation status. The units were grouped into the four following tectonic blocks (Pinto 1996): Nova Lima, Caeté, Santa Bárbara, and São Bartolomeu. These blocks represent distinct petrogenetic environments.

Along with these modifications, the formal designation of the Rio das Velhas Supergroup was kept, with the Nova Lima Group (bottom) and Maquiné (top). On the other hand, the Córrego dos Boiadeiros Complex and the Quebra Osso Group were redefined as formations within the Nova Lima Group. The Córrego dos Boiadeiros Complex was separated as an intrusive ultrabasic sill at the bottom of the Nova Lima Group (Pinto 1996, Zuchetti et al. 1996, Pinto \& Silva 1996). According to Pinto and Silva (1996), three formations (Córrego Ouro Fino, Córrego dos Boiadeiros, and Quebra Osso Formations) belong at the base of the Nova Lima Group and are present in the Caeté, Nova Lima, and Santa Bárbara Blocks (Fig. 2).

Volcanogenic metasedimentary rocks of the Nova Lima Group are only exposed in the Caeté and Nova Lima Blocks and are represented by the intercalation of felsic pyroclastic, and epiclastic horizons. Gradational layering, small cross stratification and turbiditic structures are commonly preserved. Fine-grained carbonaceous schists also occur and are interpreted as metapelites. They are intercalated in the sequence and were designated as the Lapa Seca Formation by Ladeira (1980). On the other hand, the volcanoclastic metasedimentary rocks occur in the Caeté Block

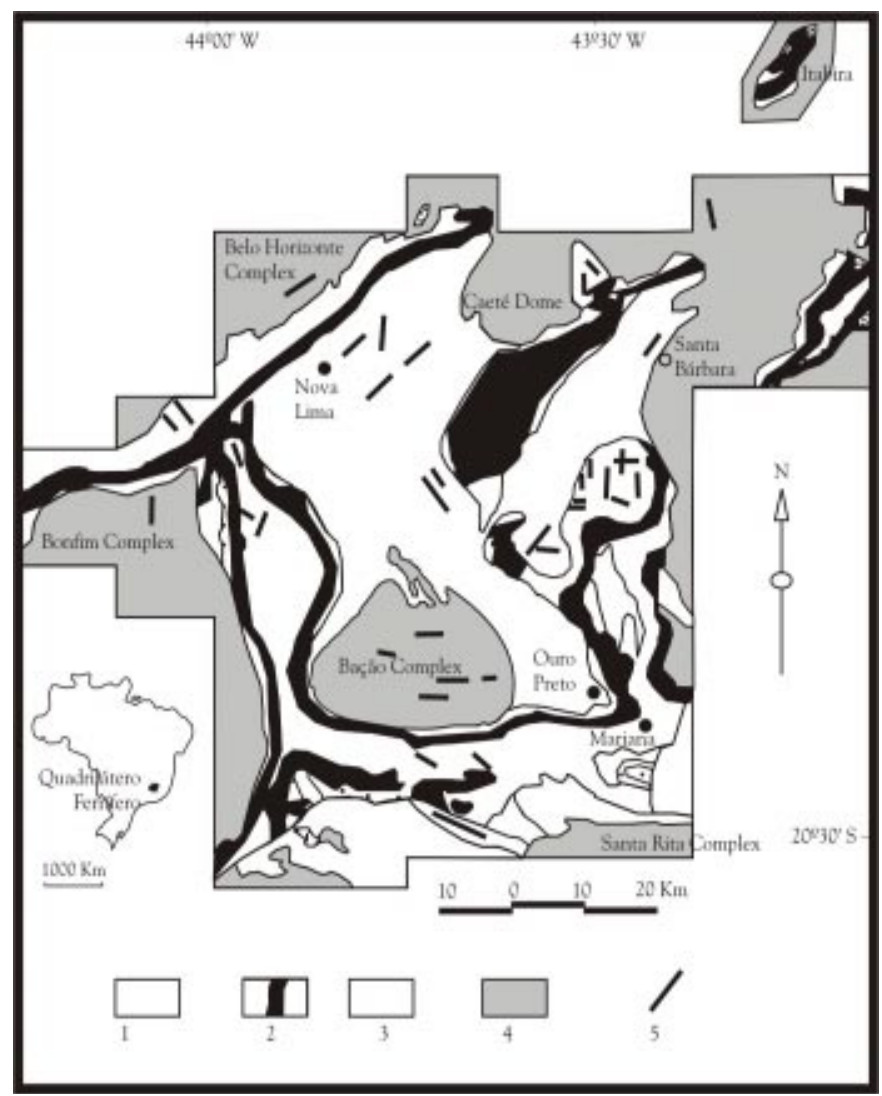

Figure 1- Geological sketch of Quadrilátero Ferrífero (Modified from Dorr 1969). 1-Granite-gneiss terrains, 2-Rio das Velhas Supergroup, 3-Minas Supergroup, 4-Espinhaço Supergroup, 5 Mafic dykes swarms.

and were named the Ribeirão Vermelho Formation. This formation consists of pyroclastic dacitic tuff and agglomerate with subordinated flows flows (Pinto \& Silva 1996, Fig. 2).

The metasedimentary rocks were previously assigned to six formations: Córrego do Sítio (Caeté, Nova Lima and Santa Bárbara Blocks), Mindá (Caeté, Nova Lima and Santa Bárbara Blocks), Catarina Mendes, Córrego da Paina, Fazenda Velha and Pau D'Óleo (São Bartolomeu Block) (Pinto \& Silva 1996, Fig. 2).

Tectonic Evolution The Quadrilátero Ferrífero is marked by a complex multi-phased history, which resulted in the heterogeneous superposition of successive tectonic events. Granite-gneiss terrains older than $3000 \mathrm{Ma}$ are considerably more complex than younger ones. In addition, younger ones that have yielded 2700 to $2800 \mathrm{Ma}$ ages have a NS foliation with horizontal mineral lineation, which formed coevally with the NS structures of QF, which are well displayed in the Bonfim Complex (Chemale Jr. at al. 1991, 1994).

Endo \& Carneiro (1996) proposed that the deformation and its successive reactivations, during the Neoarchean, was formed within a transpressional tectonic regime. The NS structures are deflected in some places, such as in the Bação Complex and surrounding features (Endo et al. 1996a). Such deflection was interpreted by Endo et al. (1996a) as the result of the Bação Tectonic Complex presence that would have nucleated during the crustal 


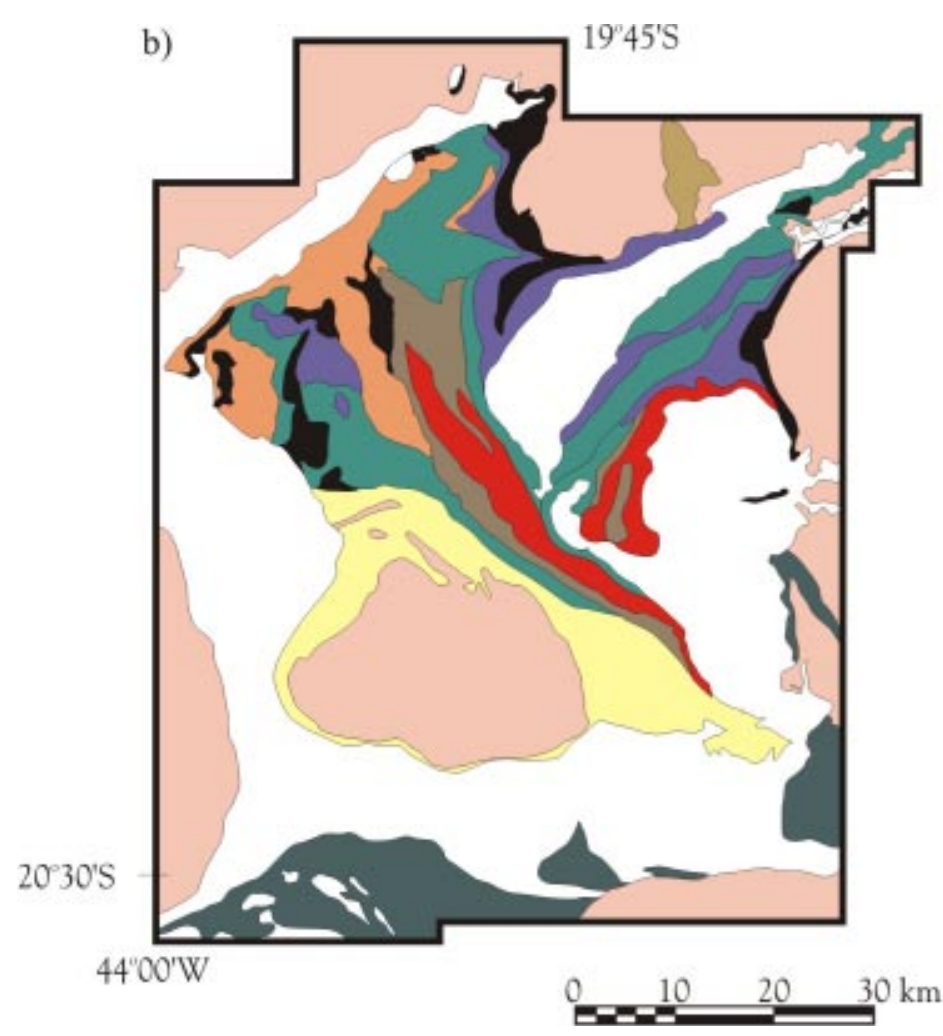

\section{LEGEND}

Espinhaço Supergroup

Minas Supergroup

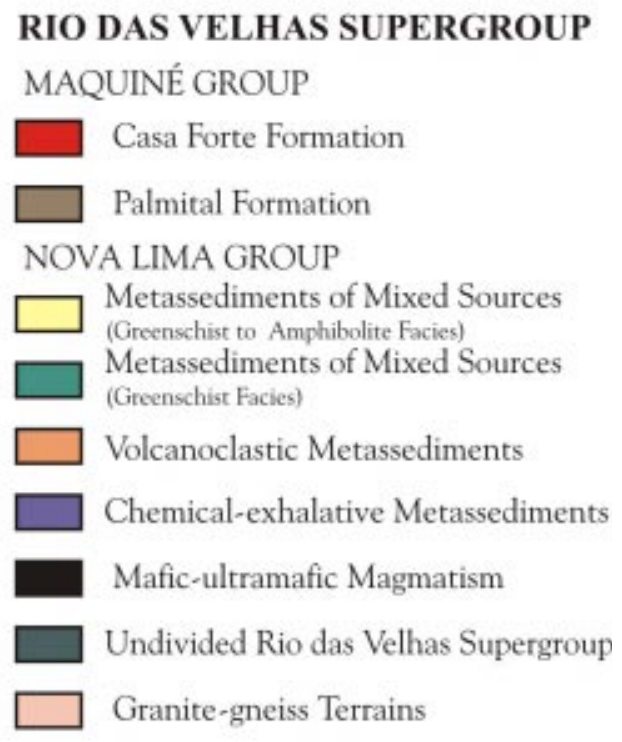

Figure 2 -Simplified geologic map of the Rio das Velhas Greenstone Belt with the new stratigraphic subdivision proposed by Pinto and Silva (1996).

fragmentation episodes. In this context, the mylonitic foliation on the margins of the complex, along with the dextral sigmoidal trajectory of the mylonitic foliation within the Rio das Velhas Supergroup, would have been generated during the oldest dextral deformation episode, about $2780 \mathrm{Ma}$.

Marshak et al. (1992) proposed that the Rio das Velhas Greenstone Belt possesses dome-and-keel structures. The supracrustal sequences having been placed in narrow synformal depressions between domal metamorphic complexes. These authors demonstrated that the dome-and-keel structures are younger than the volcano- sedimentary sequence, and the majority of the younger GGT's granitoids. The structures involved the Paleoproterozoic Minas Supergroup. According to Marshak et al. (1992), the generation of dome-and-keel structures would occur through the almost-diapiric ascension of the metamorphic complex bodies in an extensional environment associated with partial melting that generated felsic magmas, which in turn formed contact metamorphic aureoles in the intruded supracrustal rocks. Chemale Jr. et al. (1991 and 1994) interpreted the domes of the Quadrilátero Ferrífero to have formed about $2.0 \mathrm{Ga}$ as the result of crustal extension, similar to the formation of the metamorphic core complexes in the southwestern United States.

Gold Mineralization According to Ribeiro-Rodrigues (1998), the QF gold production reached approximately $910 \mathrm{t}$. Archean greenstone-hosted deposits are responsible for $53 \%$ of this production and constitute the majority of the inactive and active mines, such as: Cuiabá (Ribeiro-Rodrigues et al. $1996 \mathrm{a}, \mathrm{b}$, c and Ribeiro Rodrigues 1998), São Bento, Raposos (Godoy 1994), Lamego
(Carmo in prep.), Morro Velho (Ladeira 1988), Córrego do Sítio (Takai et al. 1991) and Juca Vieira. Proterozoic sediment-hosted deposits have contributed approximately $8 \%$ of the gold production, while Cenozoic deposits have contributed almost $39 \%$ of the production.

Banded iron formations are by far the most important hosts of gold mineralization. They can be divided into three types: oxide type (Raposos, Espírito Santo), carbonate-sulphide type (Cuiabá, Lamego) and ankerite/ferroan dolomite, quartz and plagioclase type (Lapa Seca-Morro Velho, Bicalho, Juca Vieira). These three types account for $99 \%$ of the gold production (approximately $540 \mathrm{t}$ ). They are associated mainly mafic volcanics (metabasalts and metaandesites) and carbonated pelites, which, sometimes are mineralized adjacent to banded iron formations.

In terms of the amount of contained gold, the Lapa Seca (Mestre Caetano Unit) is the major host. Also, BIF and chert host significant economic grade-mineralization and account for $14 \%$ of the total gold production (Ribeiro-Rodrigues 1998). The common wallrock alteration is sulphidation and silicification in the BIF's, sericitization, carbonatization, chloritization, and sulphidation in the mafic rocks, and carbonatization, sericitization, and sulphidation in the metasedimentary rocks. However, in terms of the number of individual deposits, BIF is the principal host, with $62 \%$ of the deposits.

STATISTICALMETHODOLOGYAND DATA A method based on comparative statistics is applied to grids of the airborne geophysical data to determine whether or not there exists a characteristic signature over particular geologic units with known high potential for gold mineralization. In general, the method calculates 
a ratio of probabilities, defined here as weights, which numerically describe how well a particular evidential data layer predicts a given training area. The higher in value the weight, the stronger the spatial association and the more likely the particular evidential layer predicts the location of a given training region.

THE DATA SETS A variety of regional data sets from Rio das Velhas Greenstone Belt have been registered and analyzed using a geographic information system (GIS). The data sets include Rio das Velhas Project geological map (reference), Rio das Velhas airborne geophysical survey data (airborne magnetic, radiometric and frequency domain electromagnetics), and terrain. Gridded aeromagnetic, electromagnetic and four channel radiometrics data were used as evidential layers to predict favourable host rocks and mineralized environments (Silva 1999 and Silva et. al., in this issue). As described in Silva (1999) and Silva et. al. (this issue), different steps were employed to enhance the predictive layers and prepare them for modeling. The data used as evidential layers and the choice of training areas were selected to reflect as much as possible some of the current ideas about gold genesis in the area. The calculation of probability ratios was carried out on raster versions of the geologic, mine, geophysical data represented on 50-meter pixels with ER Mapper 6.0 and ERDAS Imagine 8.3. Different classes of each information layer were considered candidates for this analysis. Some assumptions are considered in these cases:

- The geological map of the study area and the host rocks (Morro Vermelho and Santa Quitéria units) are known and used as predictor of mineral potential of oxide BIF-hosted-gold mineralization. The goal is to define the geophysical signature around host rock and then extend this information into unknown areas.

- The resulting weights represents the measures of the spatial correlation between the host rock and input data set (geophysical data). Values greater than 1 indicate a positive association between the tested class and tested domain, a value less than 1 suggests a negative association and a value equal one implies a random association. For example, a weight of 12 for a class implies that class is 12 times more likely to be found within the reference area as in the other (non-reference) areas in the study area.

Calculation of probability ratios Probability ratios were determined for each input map and reflect the correlation between host rocks with occurrences and deposits. After probability ratios were calculated, a composite model was created showing the probability of occurrence based on accumulated evidence from the input maps. In simplified terms, probability ratios can also be represented as follows:

\section{$\mathbf{P R}=\underline{\text { Overlap area/Tested Class Area }}$}

Prototype area/Study Area

Where the overlap area is defined as the overlap between the prototype (favourable geologic formations) and the tested class (classes in the geophysical data). The prototype area for this study is the oxide-type banded iron formation (BIF) or favourable geologic-host units with great amount of oxide-type BIF. The study area is the area covered by the airborne geophysical survey.

The expression above is equivalent to the ratio of two probabilities. The probability ratios can be expressed as the following formula:

$\mathbf{P R}=\underline{\text { Conditional Probability }}$ Prior Probability

The conditional or posterior probability (numerator) represents the odds of finding the test class within a reference area. The prior probability or unconditional probability (denominator) describes the odds of being in the prototype area if no conditions are known about the location of the tested class, except that the prototype is located somewhere within the study area. We measure the relative likelihood of finding the prototype within each tested class area compared to the likelihood of finding the prototype within the study area (McCafferty et al. 1999, Silva 1999).

One major assumption is made prior to calculating additive predictive models: that the input maps are conditionally independent. This assumption is important for models in which weights of different layers are to be combined additively. If conditional dependence is present among two or more layers, the resulting model values will be inflated by essentially double weighting of conditionally dependent variables. If the expert uses input maps that are not related, the conditional dependence is automatically avoided. Furthermore, although it is probably unlikely that conditional dependence can be completely, it is not devastating to the results of modeling if the expert is using the models to indicate favorability or ranked potential. Bonham-Carter et al. (1989) suggest that this assumption can be tested. Either chi-square or pairwise tests can be applied, showing the degree with which each input maps satisfies the conditional independence with respect to the prototype areas.

DEVELOPMENT OF PREDICTIVE MODELS FOR BIFHOSTED GOLD Geologic units host large deposits of oxideBIF gold mineralization, which include the Morro Vermelho and Santa Quitéria units (Silva 1999, Fig. 2), are used as training regions. We use the airborne geophysical data (magnetic, electromagnetic, and radiometric) as the evidential layers (Silva 1999). Our initial hypothesis is that BIF units will likely have a characteristic geophysical signature that can be used to predict the locations of similar types of lithologies. Because of the ability of the magnetic and electromagnetic data to image through vegetation and soil cover, we expect that many of the areas mapped by the approach may locate similar types of BIF at depth.

Fundamental lithological, mineralogical, and structural controls on gold mineralization are summarized in order to establish a geologic framework from which the geophysical predictive models were built. This section describes the "expert" knowledge component of the model building efforts and results primarily from extensive literature research and secondary field studies of banded iron-hosted gold deposits in the Rio das Velhas study area.

Lithological Controls The Archean greenstone-hosted gold deposits are related to the volcano-sedimentary successions of the Nova Lima Group, mainly with Fe-rich lithologies such as carbonate -facies iron-formations, and mafic volcanics. Those deposits occur at the ultramafic, felsic and mafic volcanics, clastic and chemical sediments and are characterized by common features (Ribeiro- Rodrigues 1998).

The common wallrock alteration is the sulphidation and silicification in the BIFs, sericitization, carbonatization, chloritization and sulphidation in the mafic rocks and carbonatization, sericitization and sulphidation in the metassediments.

The oxide-banded iron formation was studied, because it is an important host and occurs in different positions within the Nova Lima Group. The objective in this case is try to map the likelihood of BIF inside of Rio das Velhas Greenstone Belt.

The banded iron formations are by far the most important hosts 
of economically viable gold deposits and have been contributing $99 \%$ of the whole gold production. These banded iron formations have different geological and different physical properties and can be divided in three types: oxide, carbonate-sulfide and ankerite/ ferroan dolomite, quartz and plagioclase type (Lapa Seca). In terms of the amount of contained gold, the Lapa Seca (interlayered with the Mestre Caetano Formation) is the major host lithology. Oxidetype BIFs, containing significant economic grade-mineralization, host $62 \%$ of the known gold-bearing deposits in the area.

Mineralogical Controls Usually, the ore is composed of pyrite, pyrrotite, arsenopyrite, sometimes, with smaller quantities of calcocite, sfarelite and galena. The percentages of these mineral phases vary not only among different deposits, but also within the deposits themselves. Gold is associated with sulfides, occurring as inclusions, in fractures or along grain boundaries (Ribeiro Rodrigues 1998).

Structural Controls The Quadrilátero Ferrífero has a complex multi-phase history characterized by the heterogeneous superposition of successive tectonic events, which is an important factor in controlling the distribution of the gold. One important feature that indicates structural control is the remarkable down-plunge continuity of the ore bodies, parallel to the stretching lineation, and mineralization in shear zones within metavolcanics (Vieira 1991a and 1991b, Scarpelli 1991, Ribeiro-Rodrigues et al. 1996 a, b, c, Ribeiro-Rodrigues 1998).

\section{PREDICTIVE MODELSFOR FAVOURABLE HOST ROCKS}

Weights that describe the degree or strength of the spatial association between various geophysical data layers with the geologic units of the Morro Vermelho and Santa Quitéria Formations were calculated using the procedure given in Silva (1999). Integrated predictive models that combine a number of statistically significant geophysical data are presented with a description of the mathematical and geologic rationale.

Predictive Model Construction Probability ratios were calculated to determine if the geologic units with known potential for gold mineralization have characteristic magnetic, electromagnetic and radiometric signatures. An initial effort was made to calculate probability ratios for all geophysical and derivative data layers. Analyses were conducted among RTP, derivative products of RTP, analytic signal amplitude, K, U, Th, total count and conductivity data and their derivative products.

Although probability ratios were calculated for all the geophysical data layers, only some products were determined to have spatial association with the select geologic units and incorporated in final models.

Predictive models for favorable host rocks and mineralized environments were generated for this study using the sum-of-weights approach. This approach was successfully used to generate predictive models for a regional study in Montana (Lee et al. 2001) and a mineral resource study in southeast Alaska (McCafferty et al. 1999). Co-registered pixels were added to create composites of multiple layers of geophysical and radiometric information. Only those pixels with probability ratios greater than 2 were considered for incorporation into final models. Additionally, each pixel present in final models that incorporated more than one evidential layer represents a either sum of probability ratios between multiple data layers or null values. For this reason, the minimum weight for any predictive model is $4(2+2)$. For example, for pixels where there is a probability ratio for conductivity but not for magnetization, these pixels are assigned a null value. In the summing process, one of the weights is rejected and is assigned a null value in final predictive model.

BIF-HOSTED GOLD PREDICTIVE MODEL Oxide-bandediron formation, Morro Vermelho Formation, and Santa Quitéria Formation predictive geophysical model illustrate one of the best models for the study area (Fig. 2). These units are represented in both the magnetization (terrace of high pass) and conductivity maps as high values with relatively high probability ratios indicating strong spatial associations with the oxide banded-iron-formation (Fig. 3) (Silva 1999 and Silva et al., this issue).

The terracing technique was applied to aeromagnetic data after it was reduced-to- pole to create a terrace-magnetization map. However, the long wavelengths, present in the reduced-to-pole data, did not permit to see the shorter wavelength anomalies corresponding to important features related to mineralization. Because of that, the terrace filter was applied to the high-pass. The goal was to point out the form and amplitude of magnetic responses of mineral deposits in the Rio das Velhas Greenstone Belt, where the highest concentration of the important mineralized sites is located.

Grid of $4175 \mathrm{~Hz}$ resistivity converted to conductivity was terraced to produce inferred conductivity maps. These maps emphasize abrupt boundaries between rocks with different conductivities. Map emphasizes boundaries between different rocks with varying conductivities. The most important host rocks or mineralized domains show high conductivity response. There is a strong correlation of these domains with the mapped Morro Vermelho and Santa Quitéria Formations. Such domains that host the known gold mineralization, illustrating the utility of this layer to improve the model and the understanding of mineralization.

Analysis of the radiometric data indicated no spatial association with these geologic units. Probability ratios are all less than 2 for potassium, uranium, and thorium indicating no characteristic radiometric signature. The uranium shows depletion in the high concentration range values, which is characteristic of tropical terrains. Since none of the three radiometric channels had weights greater than 2 these data layers were not incorporated in the final predictive model.

Figure 3 shows a predictive model for oxide-BIF geologic units based on the analysis of derivative products calculated from magnetics and $4175 \mathrm{~Hz}$-electromagnetics. A sum-of-weights model was created from the magnetization and conductivity data with weights that range from 4 to 25 . Areas mapped on Figure 3 represent tracts of ground with favourable conditions to map oxide BIF-host rocks. The modeled areas similar geophysical properties as the known oxide BIF geologic units.

Field Verification of Predictive Model for Oxide-Type Banded Iron Formation A modeled area of oxide-BIF was ground truthed with geologic fieldwork (Fig. 4). Fieldwork discovered an unmapped exposure of banded iron formation hosted in the Córrego do Sítio Formation. The geologic exposure is smaller than the model predicts. Most likely, the unit extends into the shallow subsurface and demonstrates the ability of the probability ratio technique to map shallow subsurface geology. Although ground follow-up and drill data is required to verify this inference, the approach shows encouraging potential to identify possible shallowly buried favourable host. 


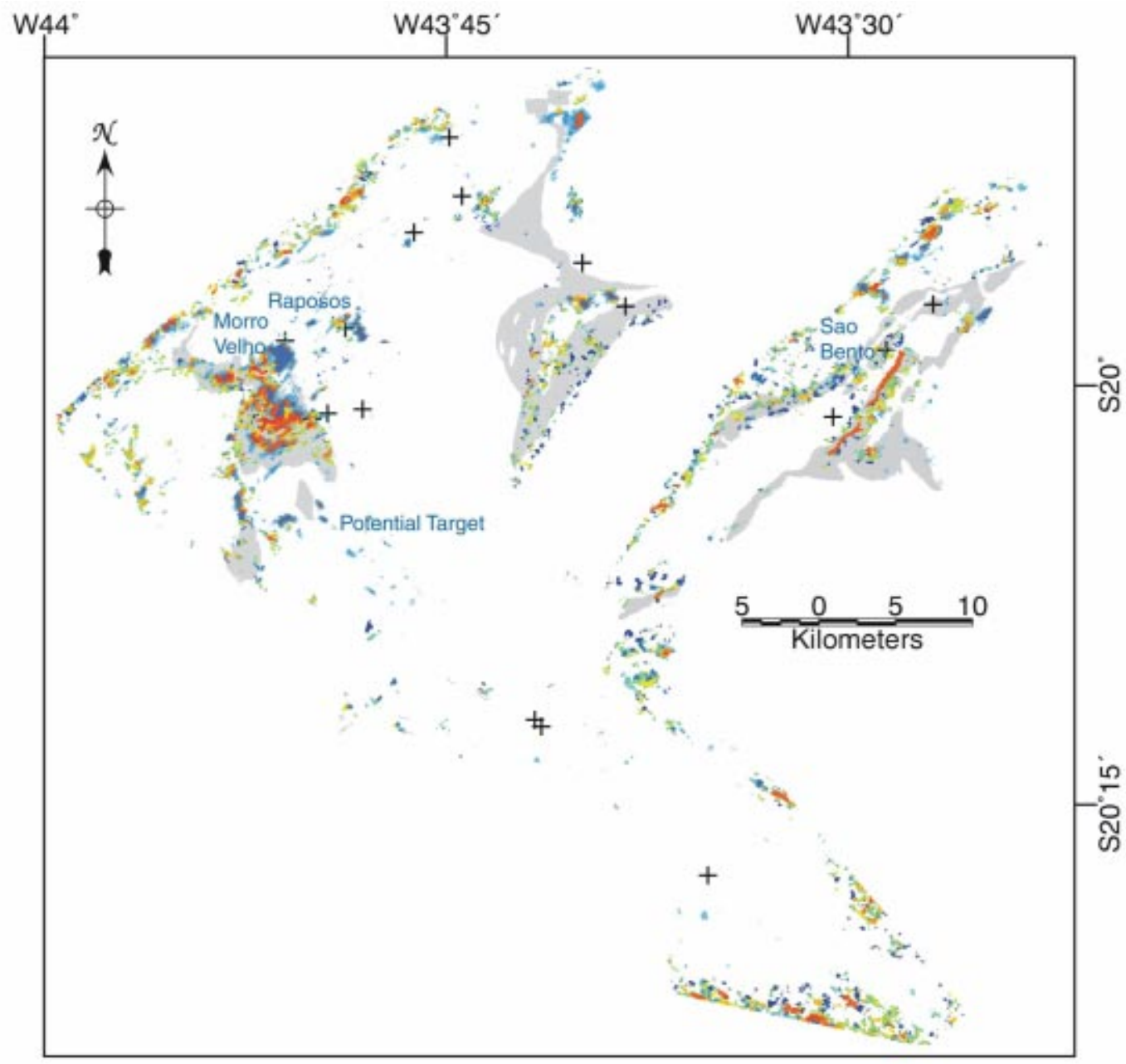

Figure 3 - Predictive geophysical model for hosts of magnetic banded iron gold mineralization. Probability ratios range from 4 (blue) to 25 (red) and would define combinations of high magnetizations and conductivities values that are 4 to 25 times more likely to map the magnetic BIF than any other geologic unit in airborne survey area. Light gray shows mapped extent of geologic units with strong associations with magnetic BIF hosted gold mineralization. Select mines names are labeled, as is the potential target for host of gold mineralization.
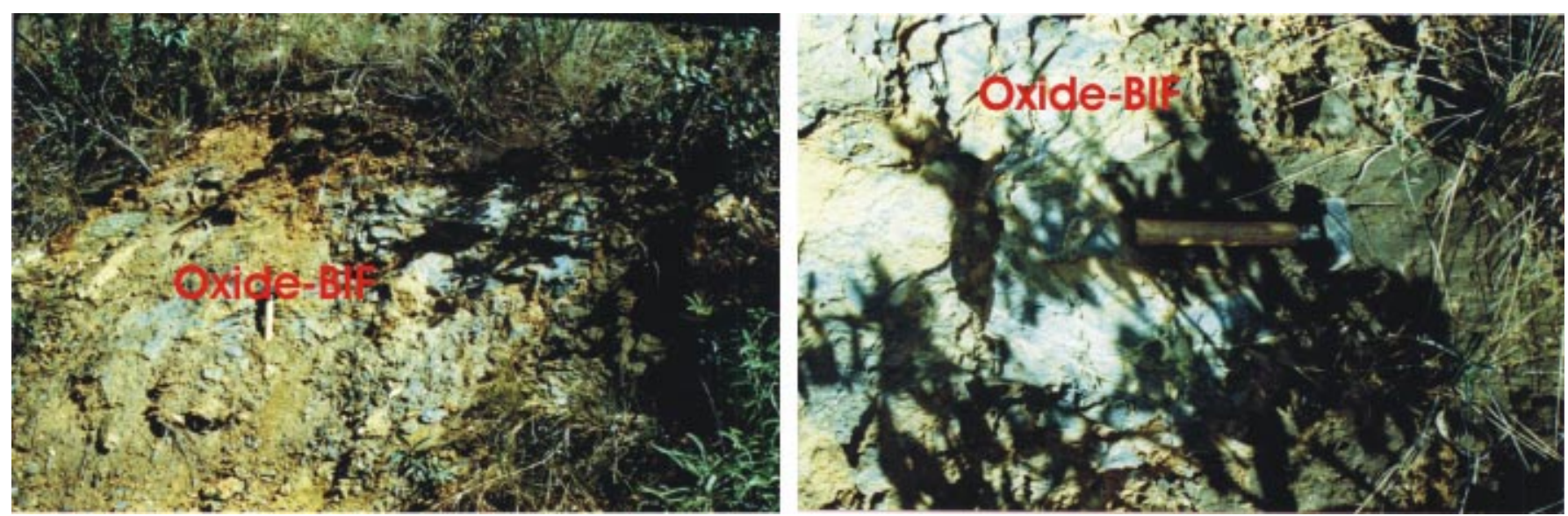

Figure 4 - Oxide-banded iron formation hosted in the Córrego do Sítio Formation, northwest of the Rio das Velhas Greenstone Belt. Target mapped with the predictive geophysical model presented in the Fig. 3. 
This model illustrates an association in the geophysical data that helps characterize geological units important to mineralization (Fig. 3). Through the probability ratio mapping approach, it is possible to observe the geologic units that have strong spatial associations with oxide-banded iron formation, chemical exhalative and volcanoclastic metassediments.

CONCLUSIONSANDTARGET CONCEPTIONS This paper focuses mainly on development of the probability ratio mapping technique and its application on prediction of the distribution of oxide-type BIF-hosted gold deposits in the Rio das Velhas Greenstone Belt, Quadrilátero Ferrífero. The probability ratio models use the spatial distribution of host rocks to calculate different multi-map signatures for gold mineralization.

The ability of the models to predict regions favorable to gold mineralization was verified by comparing them with the occurrences of Archean-greenstone-hosted gold deposits and host rocks (Silva, 1999, Silva et al. 1999). From the regional perspective, the predictive geophysical model convincingly defines the known host rocks. Most importantly, the predictive model delineate prospective areas different from those in which are the known mines. These areas have the potential to contain similar mineralization.

The predictive model leads to a consideration about the future mineral exploration efforts in the Rio das Velhas Greenstone Belt. The characterization of favorable host rocks and several of the large current and past-producing gold mines in the area provide tools for this discussion. If the veracity of these predictive models is ground truthed and confirmed, then the results will help to conduct new exploration activities in the region. This approach should consider high-potential host rocks, such as extension areas of highly prospective nature and potential targets mapped by this technique.

Acknowledgments The first author would like to thank CNPq for concession of the research project number 420117/01-0 that partially supported this research. We are grateful to Gregory Lee (USGS), Tracy Sole Van De Hoop (USGS), Colorado School of Mines, DNPM and CPRM for their help during the course of this work. To RBG referees for the suggestions to the manuscript.

\section{References}

Alkmim F.F. \& Marshak S. 1998. Transamazonian Orogeny in the Southern São Francisco Craton Region, Minas Gerais, Brazil: evidence for Paleoproterozoic collision and collapse in the Quadrilátero Ferrífero. Prec. Res., 90:29-58.

Almeida F.F.M. 1977. O Cráton do São Francisco. Rev. Bras. Geoc., 7:349-364.

Bonham-Carter G.F., 1994. Geographic information system for geoscientists - Modeling with GIS. Pergamon, 398p.

Bonham-Carter G.F., Agterberg F.P. \& Wright D.F., 1989. Weights of evidence modeling: a new approach to map mineral potencial. $I n$ : Statiscal minerals in earth sciences. Geological Survey of Canada, Paper 89-9:171-183.

Carmo V.E.F. in prep. A mina de ouro de Lamego, Quadrilátero Ferrífero, Brasil. Departamento de Geologia da Universidade Federal de Ouro Preto. Dissertação de Mestrado.

Carneiro M.A, Noce C.M., Teixeira W. 1995. Evolução policíclica do Quadrilátero Ferrífero: uma análise fundamentada no conhecimento atual da geocronologia U-Pb e geoquímica isotópica $\mathrm{Sm}-\mathrm{Nd}$. Rev. Escola de Minas, 48:264-273.

Chemale Jr. F., Rosière C.A. \& Endo I. 1991. Evolução tectônica do Quadrilátero Ferrífero, Minas Gerais - Um modelo (Tectonic evolution of the Quadrilátero Ferrífero, Minas Gerais. A Model). Pesquisas, 18:104-127.

Chemale Jr. F., Rosière C.A. \& Endo I. 1994. Tectonic Evolution of the Quadrilátero Ferrífero, MG, Brazil. Prec. Res., 65:25-54.

Cordani U.G., Teixeira W., Siga Jr. O. 1989. Geocronologia do Quadrilátero Ferrífero. In: XXI Semana de Estudos de Ouro Preto, SICEG, Ouro Preto, 21:27-44.

Cordani U.G., Kawashita K., Mueller G., Quade H., Reimer V., Roeser H.P. 1980. Interpretação tectônica e petrológica de dados geocronológicos do embasamento do bordo sudeste do Quadrilátero Ferrífero, Minas Gerais. Acad. Bras. Cienc., Anais...Rio de Janeiro, 52:785-799.

Derby O.A.L. 1906. The Serra do Espinhaço, Brazil. J. Geol., 14:374401.

Dorr II J.V.N. 1969. Physiografic, stratigraphic, and structural development of the Quadrilátero Ferrífero, Minas Gerais. U.S.G.S. Paper,
641-A:1-110.

Dorr II J.V.N., Gair J.E., Pomerene J.G., Rynearson G.A. 1957. Revisão da estratigrafia pré-cambriana do Quadrilátero Ferrífero. Departamento Nacional da Produção Mineral - Divisão de Fomento da Produção Mineral, 81:1-31 (avulso).

Endo I., Carneiro M.A., Machado R. 1996a. O Complexo Metamórfico Bação: um elemento estrutural anisotrópico na deformação do Supergrupo Rio das Velhas, Q.F., M.G. In: SBG, Congr. Bras. Geol., 39, Salvador. Anais ..., SBG, 1:411-413.

Gair J.E. 1962. Geology and ore deposits of the Nova Lima and Rio Acima quadrangles, Minas Gerais, Brazil. U.S.G.S. Professional Paper, Washington, 341-A:1-87.

Godoy M.L.S. 1994. Evolução tectono-metamórfica da mineralização aurífera de Raposos $(M G)$. Universidade do Estado de São Paulo Rio Claro. Dissertação de Mestrado, Universidade do Estado de São Paulo, 102p.

Harder E.C. \& Chamberlain, R.T. 1915. The Geology of Central Minas Gerais, Brazil. J. Geol., 23:341-378.

Hertz N. 1978. Metamorphic rocks of the Quadrilátero Ferrifero, Minas Gerais, Brazil. U.S.G.S. Professional Paper, 641-C: 1-81.

Jaques A., Wellman P., Wyborn D. 1997. High-resolution geophysics in modern geologic mapping. ASGO J. Austral. Geol. Geoph., 17:159173.

Ladeira E.A. 1980. Metallogenesis of Gold at the Morro Velho Mine, and in Nova Lima District, Quadrilátero Ferrífero, Minas Gerais, Brazil. London. University of Western Ontario. Ph.D. thesis, 272p.

Ladeira E.A. 1988. Geologia do Distrito Aurífero de Nova Lima, Minas Gerais. In: C. Schobbenhaus \& C.E.S. Coelho (coord). Principais Depósitos Minerais do Brasil. Brasília, DNPM/CVRV, 3:301-375.

Lee G.K. McCafferty A.E., Alminas H.V., Bankey V., Elliot J.E., Frishman D., Knepper D.H.Jr., Kulik D.M., Marsh S.P., Phillips J.D., Pitkin J.A., Smith S.M., Stoeser D.B., Tysdal R.G., Van Gosen B. 2001, Geoenvironmental assessment of Montana: United States Geological Survey Digital Data Series DDS-65.

Machado N. \& Noce C.M. 1993. A evolução do setor sul do Cráton São Francisco entre 3,1 e 0,5 Ga baseada em geocronologia U-Pb. In: SBG, Simp. Cráton São Francisco, 2, Salvador, 1993. Anais, 100- 
105.

Machado N., Noce C.M., Ladeira E.A., Belo de Oliveira O.A. 1992. U$\mathrm{Pb}$ geochronology of Archean magmatism and Proterozoic metamorphism in the Quadrilátero Ferrífero, southern São Francisco Craton, Brazil. GSA Bullettin, 104:1221-1227.

Machado N., Noce C.M., Belo de Oliveira O.A., Ladeira E.A. 1989. Evolução geológica do Quadrilátero Ferrífero Arqueano e Proterozóico Inferior, com base em geocronologia U/Pb. In: SBG, Simp. de Geol. Núcleo Minas Gerais, 5, Simp. Geol. Núcleo Brasília, 1, Belo Horizonte,Anais, 10:1-5.

Machado N., Schrank A., Noce C.M., Gauthier G. 1996. Ages of detrital zircon from Archean-Paleoproterozoic sequences: Implications for Greenstone Belt setting and evolution of a Trasamazonian foreland basin in Quadrilátero Ferrífero, southeast Brazil. Earth Planet. Sci. Let., 141:259-276.

Marshak S \& Alkmim F.F. 1989. Proterozoic extension/contraction tectonics of the São Francisco Craton and adjacent regions, Minas Gerais, Brazil: a kinematic model relating Quadrilátero Ferrífero, São Francisco Basin and Cordilheira do Espinhaço. Tectonics, 8:555-571.

Marshak S, Alkmim F.F. \& Jordt-Evangelista H. 1992. Proterozoic crustal extension and generation of dome and keel structure in an Archaean granite-greenstone terrane. Nature, 377:491-493.

Menezes Filho M.R., 1977. Projeto Três Marias. Belo Horizonte, DNPM/CPRM (Relatório Final).

McCafferty A.E. Smith B.D. Sole T.C. Karl S. Taylor C.D. 1999. Predictive Geophysical Models For Select geologic units and mineralized environments, Kuprenof and Zarembo Islands, Southeast Alaska: United States Geological Survey Professional Paper PP-x.

Noce C.M. 1995. Geocronologia dos Eventos Magmáticos, Sedimentares e Metamórficos do Quadrilátero Ferrífero, Minas Gerais. São Paulo. Instituto de Geociências da Universidade de São Paulo. Tese de Doutoramento, $128 \mathrm{p}$.

O'Rourke J.E. 1957. The stratigraphy metamorphic rocks of the Rio das Pedras and Gandarela Quadrangles, Minas Gerais, Brazil. University of Wisconsin, EUA. PhD Thesis, 106p.

Oliveira G.A.E., Clemente P.L.C., Vial D.S. 1983. Excursão à Mina de Morro Velho. In: SBG, Simp. Geol de Minas Gerais, 2, Belo Horizonte, 1983. Anais,3:497-505.

Oliveira O.A.B. 1986. As falhas de empurrão e suas implicações na estratigrafia e metalogênese do Quadrilátero Ferrífero, MG. In: SBG, Congr. Bras. Geol., 34, Goiânia, Anais, 2:1074-1087.

Pires F.R.M. 1977. Geologia do Distrito Manganesífero de Conselheiro Lafaiete, Minas Gerais. Rio de Janeiro. 344p. (Dissertação de Mestrado, Universidade Federal do Rio de Janeiro).

Pinto P.C. \& Silva L.C. 1996. Contrasting Tectono-Stratigraphic Domains in The Rio das Velhas Greenstone Belt (RVGB), MG, Brazil. In: SBG, Symp. Archaean Terranes South Am. Platform. Brasília, Anais, 23-25.

Pinto P.C. 1996. Introdução. Projeto Rio das Velhas. Mapa Geológico Integrado. Escala: 1:100.000. Texto Explicativo. Programa de Estudos Mineiros. Convênio DNPM-CPRM. DNPM-Secretaria de Minas e Energia-Ministério de Minas e Energia. Belo Horizonte, 1996, 1-10.

Ribeiro-Rodrigues L.C. 1998. Gold Mineralization In Archaean Banded Iron Formation, Quadrilátero Ferrífero, Minas Gerais, Brazil - The Cuiabá Mine. Rwth Aachen, Germany, Aachener Geowinssenschftiche. Tese de Doutoramento, 262p.

Ribeiro-Rodrigues L.C., Friedrich G., Oliveira C.G. 1996b. Gold mineralization in Archaean banded iron formations in Brazil. In: Intern. Geol. Congr., 30, Beijing, Extend Abstracts, 3:756.

Ribeiro-Rodrigues L.C., Friedrich G., Oliveira C.G., Vieira F.W.R., Callegari
L.A., BiasiE.E. 1996a. Ore textures and structures of the Archaean banded iron formation Cuiabá gold deposit, Iron Quadrangle, Minas Gerais, Brazil. Zbl. Geol. Und Palaont. Teil. I, 1994, (7/8):627-642.

Ribeiro-Rodrigues L.C., Friedrich G., Oliveira C.G., Vieira F.W.R., BiasiE.E., CallegariL.A. 1996c. The BIF-hosted Cuiabá gold deposit, Iron Quadrangle, Minas Gerais, Brazil: characteristics, controls and genesis. In: SBG, Simp. Gold Deposits of South America Symposium, Congr. Bras. Geol., 39, Salvador. Anais, 7:224-228.

Romano A.W. 1989. Evolution tectonique de la région $N W$ du Quadrilatère Ferrifère - Minas Gerais, Brésil. Nancy, França. Thèse Docteur, Université de Nancy I, 259p.

Romano, A.W., Bertrand J.M., Michard A., Zimmermann J.L. 1991. Tectonique tangencielle et décrochements d'âge Protérozoique inférieur (orogenèse transamazonienne, environ $2000 \mathrm{Ma}$ ) au Nord du Quadrilatère Ferrifère (Minas Gerais, Brésil). Comp. Rend. l'Académie des Sciences de Paris, 313:1195-1200.

Scarpelli W. 1991. Aspects of gold mineralization in the Iron Quadrangle, Brazil. In: Ladeira, E.A. (ed), Brazil Gold'91. Balkema, Roterdam, 151-158.

Schorscher H.D. 1976. Polimetamorfismo do pré-cambriano na região de Itabira, Minas Gerais, Brasil. In: Congresso Brasileiro de Geologia, 22, Ouro Preto. Boletim de Resumos... SBG, 194-195.

Schorscher H.D. 1978. Komatiitos na estrutura greenstone belt Série Rio das Velhas. Quadrilátero Ferrífero, Minas Gerais, Brasil. In: SBG, Congr. Bras. Geol., 30, Recife, Anais, 1:292-293.

Silva A.M. 1999. Integração de dados geológicos e geofísicos utilizandose uma nova técnica estatística para seleção de alvos para exploração mineral, aplicada ao Greenstone Belt Rio das Velhas, Quadrilátero Ferrífero. Instituto de Geociências, Universidade de Brasília, Brasília. Tese de Doutoramento, 195p.

Silva A.M. McCafferty A.E. \& Pires A.C.B. -1999 - A new approach to map host rock for gold exploration in the Rio Das Velhas Greenstone Belt, Quadrilátero Ferrífero, Minas Gerais, Brazil. Intern. Congr. Brazilian Geoph. Soc., 6, Proceedings, 1999, CD.

Takai V., Pinto L.C., Duquini Jr. J. 1991. The Córrego do Sítio gold deposit. In: LADEIRA E.A. (ed), Brazil Gold'91. Balkema, Roterdam, 811-816.

Teixeira W. 1985. A Evolução Geotectônica da Porção Meridional do Cráton São Francisco, com Base em Interpretações Geocronológicas. Instituto de Geociências, Universidade de São Paulo, São Paulo. Tese de Doutoramento, 207p.

Vieira F.W.R. \& Oliveira G.A. 1988. Geologia do Distrito Aurífero de Nova Lima, Minas Gerais. In: C. Schobbenhaus \& C.E.S. Coelho (coord). Principais Depósitos Minerais do Brasil. Brasília, DNPM/ CVRV, V(3): 377-391.

Vieira F.W.R. 1991a. Textures and processes of hydrotermal alteration and mineralization in the Nova Lima Group, Minas Gerais, Brazil. In: Ladeira, E.A. (ed), Brazil Gold'91. Balkema, Roterdam, 319-327.

Vieira F.W.R. 1991b. Petrologia e litogeoquímica do Setor W do "Greenstone Belt" Rio das Velhas, MG. In: Simpósio Internacional de Geologia do Grupo AMSA, 1, Nova Lima, 1991, Mineração Morro Velho internal report, $17 \mathrm{p}$.

Zucchetti M., BaltazarO.F., Raposo F.O. 1996. Estratigrafia. Projeto Rio das Velhas. Mapa Geológico Integrado. Escala: 1:100000. Texto Explicativo. Programa de Estudos Mineiros. Convênio DNPMCPRM. DNPM-Secretaria de Minas e Energia-Ministério de Minas e Energia. Belo Horizonte, 1996, 13-42.

Manuscrito SR-04

Recebido em 29 de agosto de 2002

Revisão dos autores em 25 de março de 2003 Revisão aceita em 21 de abril de 2003 